\title{
The response of invertebrate communities to a moisture gradient in artificial soils of Ukrainian steppe arid zone
}

\author{
A.V. Babchenko ${ }^{1 *}$, M.P. Fedushko ${ }^{2}{ }^{2}$, E.I. Timchiy ${ }^{1}$, Yu.A. Huska ${ }^{1}$, S.V. Khalus ${ }^{1}$ \\ ${ }^{1}$ Ukrainian State University of Chemical Technology, 8 Gagarin Av, 49005, Dnipro, Ukraine \\ ${ }^{2}$ Bogdan Khmelnitsky Melitopol State Pedagogical University, 20 Hetmanska St, 72318, Melitopol, Ukraine \\ Corresponding author e-mail: lineanna83@gmail.com \\ Received: 16.11.2020. Accepted: 22.12.2020
}

\begin{abstract}
Animals were sampled within the experimental area using traps to investigate the spatial and temporal variation in abundance, species richness, and species composition of invertebrate communities. A total of 60 traps were operated simultaneously during each sampling period. Traps were emptied 26 times every 7-9 days each year. Plant water availability, precipitation, wind speed, air temperature (minimum, maximum, daily mean), air humidity, and atmospheric pressure were used as ecological predictors of invertebrate community status and structure. Two-dimensional geographic coordinates of sampling locations were used to create a set of orthogonal spatial variables based on eigenvectors. We used time series of sampling dates to produce a set of orthogonal eigenvector time variables. The moisture content in technosols was the most important factor determining the terrestrial invertebrate community's temporal dynamics under semi-arid climate and reclaimed ecosystem conditions. Each ecological group of terrestrial invertebrates is homogeneous in terms of moisture gradient (xerophilic, xerozoophilic, mesophilic) and has a specific set of patterns best explain the species response to water content in technosols. However, one should consider the fact that the species response to soil water content is influenced not only by soil water content but also by a complex of other environmental, temporal and spatial factors. That is why the effect of other factors on the species response must be extracted previously to find real estimations of the species optima and tolerance. This task can be solved using the constrained correspondence analysis (CCA) or constrained redundancy analysis (RDA) depending on the type of response to ecological factors prevailing in the community - monotone or unimodal. We found that in more dry conditions, the prevalent species responses are unimodal asymmetric, in moister - bimodal, and in moderate conditions, the distributions are symmetric unimodal. The asymmetric species response to soil moisture in different parts of the soil humidity range may be assumed as predominantly due to the abiotic factors in the gradient's aridest margin and due predominantly to the biotic factors in the most humid margin of the gradient.
\end{abstract}

Keywords: species response, niche, optima, tolerance, reclamation, gradient, temporal dynamic

\section{Introduction}

The measurement of niche properties concerns such questions as the problem of range, spacing, and the problem of nonlinearity (Colwell, Futuyma, 1971). The shape of the response curves has theoretical and practical importance (Austin, 1999). The niche may be quantitatively described by niche position and niche width (Gregory, Gaston, 2000). The species response parameters like optima or niche width depend on the model shape (Jansen, Oksanen, 2013) and can be used to explain the ecological behavior of species (Michaelis, Diekmann, 2017). Apart from the optimum, all model attributes are heavily influenced by the data set's properties, which is why it appears to be challenging to establish the "true" niche characteristics of a species (Michaelis, Diekmann, 2017). Niche width (or niche breadth, niche size, versatility) is the distance through a niche along some particular line in niche space (Colwell, Futuyma, 1971; Smith, 1982). Niche width is essentially the inverse of ecological specialization (Kohn, 1968). The different aspects of the niche size such as climatic tolerance, habitat, or diet breadth were revealed to affect the species range size (Gaston et al., 1997). The term specialization is used for different biological organization levels (individual, species, population, or community) and measured at very different spatial scales (Devictor et al., 2010). The intraspecific and interspecific interactions and environmental conditions affect niche position and niche width (Brown, 1999; Lawton, 1999). Interspecific competition is a dominant force in animal communities that induces niche shifts (Tarjuelo et al., 2017). The general diversity theory integrating metabolic principles with niche-based community assembly predicts that a decrease in temperature should reduce niche widths along environmental gradients due to decreasing growth rates. The changing niche widths should lead to contrasting a $\beta$-diversity patterns (Okie et al., 2015). The temporal and spatial dynamics of population abundance or community diversity may be explained based on the niche theory (Schoener, 1989; Tokeshi, 1999). Niche theory predicts that species' distribution is forced by the differences between species optima and environmental factors (Hutchinson, 1957). Environmental filtering, biotic interactions, and interspecific competition have important implications for 
species diversity and composition (Chase, Myers, 2011). A set of biotic and abiotic conditions under which a given organism can survive and reproduce is considered its ecological niche (Hutchinson, 1957). The ecological niche may be considered in the context of the two dimensions: Grinnellian and Eltonian (Soberon, 2007). The Grinnellian niche considers the importance of a given set of resources for the survival of a species (Devictor et al., 2010). The Grinnellian niche is considered in two ways: on the one hand, as a complex of the habitat conditions and, on the other hand, as behavioral adaptations allowing organisms to persist and produce offspring (Grinnell, 1917). The Eltonian niche is concentrated on considering species response to environmental impact and the consideration of species impact in the environment. The niche reflects a species' place in the biotic environment, its relations to food and enemies (Elton, 1927).

For the unimodal species response model, the simplest way to estimate the species optimum is by calculating the weighted average of the value of environmental variables in the samples where the species is present (Šmilauer, Lepš, 2014). The weighted averaging approach for species relative importance assessment was developed by Curtis and McIntosh (1951). The Gaussian bell-shaped response model is the classical and frequently used model (Gauch \& Whittaker, 1972). Suppose the relationships between species occurrences and values of a quantitative environmental variable conform to bell-shaped curves. In that case, the optimal for species values of the environmental variable may be found by averaging over the samples in which a species occurs or can be weighted by species abundance (ter Braak \& Looman, 1986). Correspondence analysis is based on the assumption of symmetrical unimodal species responses along environmental gradients (ter Braak, 1985), which is why weighted averaging is the basis of this ordination technique (Hill, 1973). The generalized linear models allow the modeling of symmetric bell-shaped response curves (ter Braak \& Looman, 1986). The Huisman-Olff-Fresco (HOF) approach provides a comprehensive set of models characterized by statistical correctness, flexibility, and ecological interpretability (Huisman et al., 1993). This model framework was expanded to comprise seven ecological niche patterns (Jansen \& Oksanen, 2013).

The terrestrial macroinvertebrate communities of arid and semi-arid ecosystems are represented by insects, spiders, mollusks, and myriapods (Gerlach et al., 2013). Among insects, the ground-dwelling beetles (especially Carabidae, Scarabaeidae, and Tenebrionidae) form the most considerable community component in the arid ecosystems (Konstantinov et al., 2009). Spiders are dominant predators and a species-rich group in most terrestrial ecosystems (Wise, 1993; Rushton, Eyre, 1992). Saprophagous macroarthropods provide a crucial role in organic matter turnover within most ecosystems (Paoletti et al., 2007). Millipedes, woodlice, and other saprophagous macroarthropods are classified as litter transformers (Lavelle et al., 1997) and represent critical regulators of plant litter decomposition within ecosystems (David, Handa, 2010). Saprophagous macroarthropods' sensitivity to environmental impacts makes them invaluable bioindicators (Paoletti, Hassall, 1999; SoutyGrosset et al., 2005). Humidity and moisture affect the activity and distribution of terrestrial isopods (Warburg et al., 1984). Climatic factors, predation, and parasitism are the frequent causes of the Isopoda population dynamic (Warburg et al., 1984). Shrub cover and herbaceous species richness were shown to be the best drivers of detritivores and species composition of the herbivores beetle community. For predator species composition, shrub height and cover were the best predictors (Liu et al., 2016). The herbivorous and predatory arthropods' range characteristics were correlated with diet breadth (Brandle et al., 2002; Beck, Kitching, 2007) and habitat breadth (Brandle et al., 2002). The distribution and abundance of spiders depend on three niche axes: wind, moisture, and temperature (Wise, 1993). Spider species occurrence is frequently related to vegetation structure, soil moisture, disturbance, and management regime (Marc et al., 1999; Bonte et al., 2002). The importance of habitat landscape properties on spider assemblages was reported (Gallé et al., 2011). Four separable spider species groups (salt meadows, dunes, meadows, and floodplain forests) along a soil salinity and moisture gradient were extracted (Buchholz, 2009). It is also important to note that several studies failed to find convincing correlations between the environment and spiders' occurrence (Mallis, Hurd, 2005). The spatial distribution of carabids around arable field-woodlot boundaries was explored using logistic curves with the Huismann-Olf-Fresco models (Knapp et al., 2019). The species-specific effects of shrub cover on Arthropoda animal groups that act as indicators of degradation were revealed due to focusing on species niche breadths and optima (Hering et al., 2019). Coexistence mechanisms at multiple scales in insect assemblages were explored with HuismanOlff-Fresco models (Laporta, Sallum, 2014). The vegetation and vegetation-soil interactions are essential determinants of beetle community assemblies. The vegetation changes had more substantial effects on the functional group composition than changes in the soil (Liu et al., 2016).

Deep underground hard-rock mining has a considerable impact on the landscape, transforming original habitats and leaving landscapes in altered states (Szczepanska, Twardowska, 1999; Hodecek et al., 2015; Klimkina et al., 2018; Zhukov, Maslikova, 2018; Yorkina et al., 2019). The landscape transformation due to open-pit coal mining causes significant changes in terrain structures, waterways, microclimates, land uses, and living organism communities (Sklenicka et al., 2004; Hendrychova et al., 2011; Yorkina et al., 2018; Zadorozhnaya et al., 2018). The technical and biological reclamation phase is essential for managing a disturbed landscape (Hildmann, Wunsche 1996; Rehor et al., 2006; Hodecek et al., 2016). The reclamation processes' technical phase is a significant disturbance that slows down the successional rate of beetle communities (Hodecek et al., 2016). The ecological niche principle has to be used for a conceptualization of the restoration of the mine- degraded lands (Zhenqi et al., 2012; Kunakh et al., 2018). The soil formation is essential for successful reclamation of post-mining sites (Madej, Kozub, 2014). The soil macrofauna distribution pattern was found to be strongly related to soil development after reclamation (Ge et al., 2014; Zhukov et al., 2018). Animal post-reclamation succession can be influenced by plant community diversity or abiotic conditions (Hendrychova, 2008; Buchori et al., 2018; Zhukov, Gadorozhnaya, 2016). The Coleoptera communities on reclaimed ecosystems were shown to be dependent upon the herb and soil cover (Hodecek et al., 2016). The species richness of invertebrate groups representing various trophic levels and diverse spatial niches was revealed to be affected by different soil properties, microclimatic conditions, and management history (Hendrychová et al., 2012). The diversity of insects in reclamation areas was revealed as being affected by environmental factors such as tree age, vegetation diversity, and soil chemistry (Dunger et al., 2001; Buchori et al., 2018). The microclimatic condition, moisture, herb cover, and forest composition were identified as the 
most significant environmental variables affecting an invertebrate community of areas remaining after opencast brown coal mining (Hendrychová et al., 2008). The epigeic invertebrates in the early stages of technosols' colonization presented a succession, indirectly linked to soil parameter changes (Hedde et al., 2018). The application of organic waste combined with revegetation led to an immediate increase in beetle numbers (Kielhorn et al., 1999). The small-sized Carabidae species with high adaptive abilities and high ecological plasticity dominate reclaimed lands (Kędzior, 2018). The "niche-breadth" hypothesis sensu Brown (1984) was applied to explain the local communities' structure in non-reclaimed mining sites (Brandle et al., 2003). Investigations of niche characteristics of the terrestrial arthropods are still rare (Entling et al., 2007), and there is no evidence about species response within terrestrial invertebrates groups to the effect of the environmental gradients of the reclaimed lands.

Drylands include arid, semi-arid, and dry subhumid areas. Water is the main limiting factor affecting the dynamic of the ecological processes in many semi-arid grassland ecosystems (Chase et al., 2000). In dryland areas, precipitation is in deficit and exhibits a high temporal variability, and is mostly unpredictable (Reynolds et al., 2007). Water, soil nutrients, and plant biomass are the essential resources in arid or semi-arid conditions, for which long periods of low abundance are interrupted by relatively short periods of high abundance. Rainfall events usually trigger short periods of high resource availability until moisture is depleted (Schwinning et al., 2004). Ecological processes in arid lands are often described by the pulse-reserve paradigm (Collins et al., 2014). High air temperatures, low humidity, and abundant solar radiation result in high potential evapotranspiration, leading to water deficit. Many dryland soils contain small amounts of organic matter and have low aggregate strength (Reynolds et al., 2007). These ecological conditions are the most extreme within anthropogenically transformed territories, including reclamation ecosystems (Hendrychova, 2008).

In this work, various approaches were applied to assess the soil moisture optimum and tolerance of the ecological niche temporal projection of terrestrial invertebrates within an experimental polygon set up to investigate the dynamics of reclamation processes after deep underground mining of hard rock in steppe arid regions of Ukraine. Our main objective was to determine whether the variability of water content in technosols affects the temporal dynamics of terrestrial invertebrates and find the properties of species response curves on soil water content.

\section{Materials and methods \\ Experimental polygon}

The research was carried out at the Research Centre of the Dnipro State Agrarian and Economic University in Pokrov city. The experimental polygon for the study of optimal regimes of agricultural recultivation was established in 1968-1970. Sampling was carried out on a variant of artificial soil (technosols) formed on loess-like loam, red-brown clay, green-grey clay, the technological mixture of the rocks, and formed on loess-like loam with a humus-rich $70 \mathrm{~cm}$ topsoil layer (the geographic coordinates of the

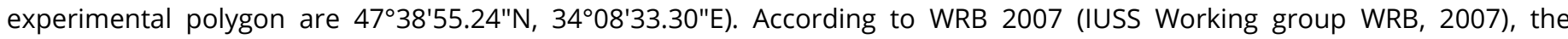
examined soils belong to the RSG Technosols. The examined profile also satisfies the prefix qualifier Spolic, having 20 percent or more artifacts (consisting of 35 percent or more of mine spoil) in the upper $100 \mathrm{~cm}$ from the soil surface. From 1995 to 2003 , a long-term legume-cereal agrophytocenosis grew on the site, after which the process of naturalization of the vegetation began (Yorkina et al., 2018). The data set comprised 20 plots from five technosol types presented within the experimental polygon.

The animals were sampled using pitfall traps to investigate the temporal dynamics in the abundance, species richness, and species composition of invertebrate communities within the experimental polygon. The term "activity-density" is employed in some studies as this value is affected by population density and animal movement activity (Knapp et al., 2019). We investigated seven invertebrate groups closely associated with the soil environment or aboveground vegetation strata: (1) mollusks (Mollusca: Gastropoda), (2) spiders (Chelicerata: Arachnida), (3) millipedes (Myriapoda: Diplopoda), (4) centipedes (Myriapoda: Chilopoda), (5) terrestrial isopods (Malacostraca: Isopoda: Oniscidea); (6) insects (Tracheata: Insecta). In total, 60 pitfall traps were operated simultaneously during each sampling period. In each plot, three pitfalls were placed in a $3 \mathrm{~m}$ base (Desender et al., 1999; Pontegnie et al., 2005) and emptied each 7-9 days. In 2013 pitfalls were placed on April 9. The pitfalls were emptied 26 times each year. The exact sampling dates were as follows in 2013: April 15, April 22, April 30, May 7, May 14, May 21, May 28, June 4, June 11, June 18, June 25, July 2, July 9, July 17, July 24, July 31, August 7, August 15, August 23, August 30, September 7, September 15, September 23, September 30, October 7, October 14. In 2014 pitfalls were placed on April 5. The exact sampling dates were as follows in 2014: April 13, April 20, April 28, May 5, May 13, May 21, May 30, June 8, June 17, June 24, July 1, July 8, July 17, July 25, August 1, August 9, August 18, August 26, September 4, September 11, September 18, September 26, October 5, October 12, October 19, October 27. In 2015 pitfalls were placed on April 6. The exact sampling dates were as follows in 2015: April 14, April 21, April 28, May 5, May 13, May 20, May 27, June 3, June 10, June 17, June 24, July 1, July 9, July 17, July 24, August 2, August 11, August 18, August 26, September 4, September 11, September 20, September 28, October 6, October 15, October 22. The pitfall traps were made of 1-liter glass cups (10 cm in diameter) buried in the soil with the cup's rim with the soil surface. The cups were filled with $250 \mathrm{ml}$ of preservative fluid made from concentrated $\mathrm{NaCl}$ solution, which seems to be efficient for collecting invertebrates and is relatively non-toxic to non-target organisms. Traps were covered by roofs made of a polyethylene sheet to prevent flooding during heavy rain. Roofs were placed $5 \mathrm{~cm}$ above the cups' openings using four long rods that penetrated the corners of the roofs.

Vascular plant species lists were recorded in 2015 for each site, and visual estimates of species cover using the nine-degree Braun-Blanquet scale (Westhoff, van der Maarel, 1978). The projective cover of plant species was recorded at ground level. We were able to make species-level identification for all sites. Based on geobotanical descriptions, phytoindicative assessment of soil humidity, according to Didukh (2011), was made. Phytoindicational evaluation of environmental factors was performed by the ideal indicator method of Buzuk (2017). 
The readily available water for plants $(R A W, \mathrm{~mm}$ in $1 \mathrm{~m}$ soil layer), precipitation $(\mathrm{mm})$, wind speed $(\mathrm{m} / \mathrm{s})$, atmospheric temperature (daily minimum, daily maximum, daily mean, ${ }^{\circ} \mathrm{C}$ ), atmospheric humidity (\%) and atmospheric pressure (gPa) were used as environmental predictors (Kunah et al., 2019). The Nikopol Meteorological Station data were used. The readily available water was calculated as follows. The daily evapotranspiration was computed based on the weather data on maximum and minimum temperature, solar radiation, relative humidity, and wind speed at $2 \mathrm{~m}$ height (Monteith, 1965; Allen et al., 1994 a, b; Allen et al., 1998; Evett et al., 2011). This approach has been tested and validated (Pereira et al., 2003; Popova et al., 2006; Jabloun, Sahli, 2008). The FAO Penman-Monteith reference evapotranspiration equation is the primary tool to calculate evapotranspiration from meteorological data (Penman, 1948; Allen et al., 1998). The Penman-Monteith equation has been revealed to be reliable in various environments (Hess, 1996). The first step of actual evapotranspiration estimation includes calculating potential evapotranspiration from meteorological data using equations based on the aerodynamic theory and energy balance (Penman, 1948; Monteith, 1965). The potential evapotranspiration is then used to estimate actual evapotranspiration after applying a soil water reduction factor based on available or extractable soil water (Slabbers, 1980). Reference crop evapotranspiration is the evapotranspiration from a crop with specific characteristics. FAO-56 method sets the specific characteristics of a reference crop with a certain height $(0.12 \mathrm{~m})$, surface resistance $\left(70 \mathrm{~s} \mathrm{~m}^{-1}\right)$, and albedo $(0.23)$ and then determines the reference evapotranspiration using the Penman-Monteith equation (Allen et al., 1998). The soil water balance is performed in ISAREG (Teixeira \& Pereira, 1992) with a daily time step as:

$$
S W_{i}=S W_{i-1}+P_{i}+l_{i}+G_{i}-E_{i}-D_{i}
$$

where $S W_{i}$ and $S W_{i-1}$ are respectively the soil water storage $(\mathrm{mm})$ in the soil layer zone at the end of day $i$ and of the previous day, $i-1 ; P_{i}$ is the precipitation; $l_{i}$ is the net irrigation depth; $G_{i}$ is the capillary rise; $E_{i}$ is the actual evapotranspiration, and $D_{i}$ is the deep percolation out of the root zone, all referring to day $i$. All units but for SW are in $\mathrm{mm} \mathrm{d}^{-1}$. $I_{i}$, $G_{i}$, and $D_{i}$ were neglected in this application.

Readily available water was found as:

$$
R A W_{i}=S W_{i}-P W P_{,}
$$

where $R A W$ - readily available water $(\mathrm{mm}), S W_{i}$ is the soil water storage $(\mathrm{mm}), P W P$ - permanent wilting point $(\mathrm{mm}) . P W P$ data were used from the article Zhukov \& Maslikova (2018). For each time pitfall exposition interval, the following environmental parameters were calculated: total precipitation sum and mean per period value of the readily available water, wind speed, atmospheric temperature, atmospheric humidity, atmospheric pressure.

Ecological structures and processes occur across multiple spatiotemporal scales (Nash et al., 2014). Ecological systems are hierarchically structured and may be decomposed into structural and process components (La Notte et al., 2017). These components can be defined over a range of spatial and temporal scales (Allen et al., 2014). The elucidation of the mechanisms underlying observed spatial and temporal patterns and different scale levels is a key to prediction and understanding to the development of management principles (Levin, 1992). The importance of stochastic processes was found to be dependent on the size of the study area (Bonsall, Hastings, 2004). The complexity has to be accounted for to model temporal patterns in time series (Baho et al., 2015). The neighbor matrix method (PCNM) 's principal coordinates are a powerful approach that can detect temporal structures of varying scales in time series data (Borcard, Legendre, 2002; Borcard et al., 2004; Dray et al., 2006). PCNM, after conversion of the time vector, produces a series of temporal variables with distinct sine-wave properties. This approach has become famous for assessing hierarchical dynamics and resilience of ecological systems (Angeler et al., 2011; Spanbauer et al., 2014). The PCNM-based approach has been further elaborated in distance-based Moran's eigenvector maps (MEM) (Dray et al., 2006; Baho et al., 2015). MEM can increase the proportion of explained variation compared to the original PCNM approach and are more robust in dealing with correlation structures (Dray et al., 2006; Baho et al., 2015).

The two-dimension geographic coordinates of sampling locations were used to generate a set of orthogonal eigenvector-based spatial variables (Spatial dbMEMs), each representing a particular scale pattern within the extent of the sampling area. Likewise, the one dimension time series of sampling dates were used to generate a set of orthogonal eigenvector-based temporal variables (Time dbMEMs), each representing a particular scale pattern within the extent of the investigated period (Borcard, Legendre, 2002). The spatial and time dbMEMs-variables were used as spatial and temporal predictors of the species responses. Weighted averaging can be used to estimate the species' optimal value along the ecological gradient in cases of the symmetric bell-shaped response curves (ter Braak \& Looman, 1986). The weighted averaging method is reasonably fair when samples cover the whole range of species distribution. The species abundances were used as the weights in calculating the ecological factor average (Šmilauer \& Lepš, 2014):

$$
W A=\frac{\sum_{i=1}^{n} \text { Env }_{i} \times \text { Abund }_{i}}{\sum_{i=1}^{n} \text { Abund }_{i}},
$$

where Envi is the value of an environmental variable in the $i$-th sample, and Abund $d_{i}$ is the abundance of the species in the $i$-th sample.

The species tolerance presented by the width of the bell-shaped curve can be calculated as the square root of the weighted mean of the squared differences between the species optimum and the actual value in the sample. The value is analogous to the standard deviation (Šmilauer \& Lepš, 2014):

$$
S D=\sqrt{\frac{\sum_{i=1}^{n}\left(E n v_{i}-W A\right)^{2} \times \text { Abund }_{i}}{\sum_{i=1}^{n} A b u n d_{i}}} .
$$

If the complete range of species distribution is covered and species response is symmetrically bell-shaped, then the weighted average estimation is correct. In contrast, the estimate is biased if only a part of the range is covered. In this case, the estimate is shifted concerning real value in the tail's direction that is not truncated. The number of species with truncated distribution will increase if the covered portion of the gradient is short, and as a consequence, the optimum estimates will be biased. The longer the environmental gradient, the more species will have their optima estimated correctly (Šmilauer \& Lepš, 2014). 
Generalized linear mixed models were used for modeling species-environment relationships. This approach is useful in the unimodal symmetric species response (Jamil, ter Braak, 2013). In the environment R the model can be fitted by (Oksanen, 2004): $\bmod <-\operatorname{glm}\left(y \sim x+I\left(x^{\wedge} 2\right)\right.$, family=poisson $)$

$\mathrm{b}<-\operatorname{coef}(\mathrm{mod})$

$\mathrm{u}<--\mathrm{b}[2] / 2 / \mathrm{b}[3]$

$\mathrm{t}<-$ sqrt(-1/2/b[3])

where $y$-species response, $x$ - environmental factor, $u$-species optimal value, $t$ - species tolerance.

The use of symmetric Gaussian response functions in gradient analysis is not a universal approach due to systematic deviation of the real data from the symmetric response (Austin, 1976, 1999, 2013; Austin et al., 1999). Huisman, Olff, and Fresco's (1993) hierarchical models (HOF) and symmetric response also include a skewed response. Apart from the five HOF-model two bimodal (skewed and symmetric) response shapes, they were included to cope with species restricted to gradient extremes due to competition (Jansen, Oksanen, 2013; Michaelis, Diekmann, 2017). The Huisman-Olff-Fresco models expanded by JansenOksanen (HOFJO) are ranked according to the increasing complexity of biological information contained (Huisman et al., 1993; Jansen \& Oksanen, 2013). The model I: no significant trend in space or time:

$$
y=M \frac{1}{1+e^{a}} .
$$

Model II: an increasing or decreasing trend where the maximum is equal to the upper bound $\mathrm{M}$ :

$$
y=M \frac{1}{1+e^{a+b x}} .
$$

Model III: an increasing or decreasing trend where the maximum is below the upper bound $\mathrm{M}$ :

$$
y=M \frac{1}{1+e^{a+b x}} \frac{1}{1+e^{c}} .
$$

Model IV: increase and decrease by the same rate - symmetrical response curve:

$$
y=M \frac{1}{1+e^{a+b x}} \frac{1}{1+e^{c-b x}} .
$$

Model V: increase and decrease by different rates - skewed response curve:

Model VI: bimodal symmetric responses:

$$
y=M \frac{1}{1+e^{a+b x}} \frac{1}{1+e^{c+d x}} .
$$

$$
y=M \frac{1}{1+e^{a+b x}} \frac{1}{1+e^{c+b(x-d)}}+\frac{1}{1+e^{a+b(x-d)}} \frac{1}{1+e^{c-b(x-d)}}
$$

Model VII: bimodal skewed responses:

$$
y=M \frac{1}{1+e^{a+b x}} \frac{1}{1+e^{c+b(x-d)}}+L \frac{1}{1+e^{a+b(x-d)}} \frac{1}{1+e^{c-b(x-d)}},
$$

where $y$ and $x$ are the response and the explanatory variable respectively, $a, b, c$, and $d$ the parameters to be estimated ( $b$ and $d$ have opposite signs), and $M-$ a constant which equals the maximal value which can be attained (for relative frequencies $M=$ 1 , for percentages $M=100), L-$ a constant which equals the maximal value for minor extreme value.

Huisman-Olff-Fresco models were fitted in the R statistical program (v. 3.3.1) (R Developmental Core Team, 2019) using the package "eHOF" (Jansen \& Oksanen, 2013, version 3.2.2). The stability of model choice was double-checked by bootstrapping to improve modeling results even for small data sets (100 samplings, default package setting) to ensure model robustness. The Akaike information criterion corrected for small data sets (AIC $)$ was used (Burnham, Anderson, 2002). When the two procedures differed in their choice for the best model type, the bootstrapping model was preferred (Michaelis, Diekmann, 2017). Optimum value and relative species tolerance limits, or the Central Borders, were calculated as implemented in the eHOF package (Jansen \& Oksanen, 2013). These are specified fractions of the curve maxima ( $\max { }^{*} \mathrm{e}^{-0.5}$ ) and are calculated separately for the left (LowCB) and right (UppCB) hand side of the optimum (Heegaard, 2002).

We applied multivariate ordination techniques to analyze the spatiotemporal variation in the species composition of invertebrate assemblages. For ecological data with many zeros, the Hellinger transformation is useful (Rao, 1995). In this regard, before analyses, species data were Hellinger-transformed (Legendre, Gallagher, 2001). There were no rare species represented by less than seven sites; that is why all species were included in the analyses, resulting in a final dataset of 202 species or parataxonomic units. We subjected the Hellinger-transformed abundance matrix of species to correspondence analysis (CA), constrained correspondence analysis (CCA), and constrained redundancy analysis (RDA) to extract the significant patterns of variation (Legendre, Birks, 2012; ter Braak, Smilauer, 2015). The environmental factors were fitted onto a CA-ordination by enfit function from the vegan library (Oksanen et al., 2018). The constrained ordination approaches (correspondence or redundancy analysis) allowed assessing the effects of the soil moisture as an explanatory variable on the invertebrate community with temporal, spatial, environmental factors, and technosol type as condition variables. The detrended correspondence analysis (DCA) was used to discriminate whether species responses are primarily monotonic or primarily unimodal and the length of the first significant gradient of variation in community data was estimated (ter Braak, Prentice, 1988). If gradient length is more than two standard deviations, constrained correspondence analysis (CCA) must be selected as an ordination approach. Otherwise constrained redundancy analysis (RDA) is most suitable. Species scores generated by the CA or CCA indicate the center of the species' distribution in a unimodal model. Therefore, species scores represent the niche position (optimum) of species along the extracted axes (ter Braak, Smilauer, 2002). The standard deviations of species scores quantify the niche width. If the ordination axes are correlated with environmental gradients, the scores and the associated standard deviations can be used to characterize the niche properties of each species concerning that gradient (Entling et al., 2007). For the statistical analyses, we used the appropriate procedures of Statistica (Version 5.5, StatSoft Inc., http://www.statsoft.com) or R (version 3.5.2; R Core Team, 2018). 


\section{Results and discussion}

Precipitation falls very unevenly in time on the investigated area. In 2013, the duration of rainless periods was 259 days; in 2014 - 264 days, in 2015 - 261 days. The maximum daily rainfall varied within 18-49 $\mathrm{mm}$. The highest amount of precipitation fell in the year 2015 (506.8 mm), and the lowest - in 2014 (328.9 mm) (Table 1).

Table 1. Descriptive statistics of the daily meteorological characteristics based on observations at Nikopol meteorological stations and readily available water content in the technosols (2013-2015)

\begin{tabular}{lccc}
\hline \multicolumn{1}{c}{ Parameters } & 2013 & 2014 & 2015 \\
\hline Precipitation, mm & $0.95 \pm 0.15$ & $0.90 \pm 0.15$ & $1.39 \pm 0.23$ \\
Wind speed, $\mathrm{m} / \mathrm{s}$ & $2.39 \pm 0.06$ & $2.28 \pm 0.07$ & $2.00 \pm 0.08$ \\
Temperature, $^{\circ} \mathrm{C}$ & $11.33 \pm 0.50$ & $10.89 \pm 0.56$ & $11.21 \pm 0.51$ \\
$T_{\min },{ }^{\circ} \mathrm{C}$ & $7.49 \pm 0.43$ & $6.47 \pm 0.49$ & $6.43 \pm 0.45$ \\
$T_{\max }{ }^{\circ} \mathrm{C}$ & $15.10 \pm 0.57$ & $15.17 \pm 0.62$ & $15.88 \pm 0.58$ \\
Atmospheric humidity, $\%$ & $73.37 \pm 0.78$ & $69.12 \pm 0.91$ & $69.59 \pm 0.83$ \\
Atmospheric pressure, gPa & $1014.85 \pm 0.39$ & $1014.67 \pm 0.40$ & $1009.26 \pm 0.43$ \\
Readily available water, $\mathrm{mm}$ in $1 \mathrm{~m}$ soil layer & $99.44 \pm 3.30$ & $49.14 \pm 1.34$ & $105.14 \pm 2.53$ \\
\hline
\end{tabular}

In 2013 precipitation was $345.6 \mathrm{~mm}$. The intensity of the rainfall varies throughout the year. The highest rainfall usually occurs in June and the lowest - in August. There are significant interannual differences in the intensity of rainfall. Minimum total annual precipitation in 2014 was due to decreased atypical rainfall in late winter and early winter. The average annual temperature was $11.14 \pm 0.30^{\circ} \mathrm{C}$ and was not statistically significantly different between years during the study period $(F=0.19, p=0.82)$. The temperature range was from -23.4 to $+37.8^{\circ} \mathrm{C}$ during the study period. The average wind speed was statistically significantly different from year to year $(F=8.72, p<0.001)$.

Table 2. Plant species number and phytoindicator estimation of the soil humidity condition

\begin{tabular}{|c|c|c|c|c|c|}
\hline Site & Technosols & $\begin{array}{l}\text { Species } \\
\text { number }\end{array}$ & $\begin{array}{l}\text { Soil humidity } \\
\text { indicator value }\end{array}$ & $\begin{array}{l}\text { Phytoindicator } \\
\text { estimation of the } \\
\text { readily available } \\
\text { water content, } \mathrm{mm}\end{array}$ & $\begin{array}{c}\text { The favorable eco-groups by the } \\
\text { relation of plant species to soil } \\
\text { water regime* }\end{array}$ \\
\hline 1 & \multirow{5}{*}{ Loess-like loam } & 23 & 12.6 & 123.2 & Mesophytes \\
\hline 2 & & 17 & 10.3 & 87.4 & Sub-mesophytes \\
\hline 3 & & 21 & 12.6 & 124.0 & Mesophytes \\
\hline 4 & & 15 & 12.0 & 113.0 & Mesophytes \\
\hline 5 & & 20 & 12.2 & 116.6 & Mesophytes \\
\hline 6 & \multirow{5}{*}{ Red-brown clay } & 26 & 11.9 & 110.6 & Mesophytes \\
\hline 7 & & 11 & 12.8 & 127.3 & Mesophytes \\
\hline 8 & & 31 & 8.4 & 65.7 & Sub-xerophytes \\
\hline 9 & & 30 & 8.6 & 67.7 & Sub-xerophytes \\
\hline 10 & & 13 & 12.6 & 124.0 & Mesophytes \\
\hline 11 & \multirow{2}{*}{ Green-grey clay } & 23 & 9.1 & 72.9 & Sub-mesophytes \\
\hline 12 & & 23 & 8.7 & 68.5 & Sub-xerophytes \\
\hline 13 & \multirow{4}{*}{$\begin{array}{l}\text { Humus-rich } 70 \\
\mathrm{~cm} \text { top soil layer } \\
\text { formed on loess- } \\
\text { like loam }\end{array}$} & 13 & 7.4 & 56.7 & Sub-xerophytes \\
\hline 14 & & 16 & 11.3 & 102.0 & Mesophytes \\
\hline 15 & & 26 & 12.1 & 114.7 & Mesophytes \\
\hline 16 & & 16 & 12.7 & 124.8 & Mesophytes \\
\hline 17 & \multirow{4}{*}{$\begin{array}{l}\text { Technological } \\
\text { mixture of rocks }\end{array}$} & 15 & 6.9 & 52.8 & Xerophytes \\
\hline 18 & & 16 & 9.0 & 71.5 & Sub-xerophytes \\
\hline 19 & & 19 & 9.0 & 71.6 & Sub-xerophytes \\
\hline 20 & & 20 & 6.7 & 51.2 & Xerophytes \\
\hline
\end{tabular}

Note: * - according to Didukh scale (2011).

The highest wind speed was observed in 2013, and the lowest - in 2015. The average atmospheric humidity is statistically significantly varied from year to year $(F=7.67, p<0.001)$. The highest humidity was found in 2013 , differences in humidity in 
2014 and 2015 were not significant. The mean atmospheric pressure is statistically significantly varied from year to year $(F=$ $60.22, p<0.001)$. The lowest atmospheric pressure was observed in 2015. The difference between 2013 and 2014 was not statistically significant.

In total, 35 species of herbaceous plants were found within the experimental polygon. At each site, the number of plant species varied from 11 to 31 (Table 2).

The phytoindication estimation of soil moisture was in the range 6.7-12.8 according to 23-point of the Didukh (2011) soil moisture scale. The phytoindication values can be converted to the value of the readily available water content, which can be estimated to be in the range of 51.2-127.3 mm per meter depth of the soil. The soil humidity range can be evaluated qualitatively as favorable for plants range from xerophytes to mesophytes.

In total, 257,437 invertebrate (Arthropoda and Mollusca) individuals of 6 classes, 13 orders, 50 families, and 202 species or parataxonomic units were recorded. Diplopoda was the most abundant taxonomic group, though it was represented only one species Rossiulus kessleri (Lohmander, 1927). This species took up $49.4 \%$ of the total community abundance. Coleoptera and Araneae were the considerably numerous taxonomic groups, which took up 22.4 and $18.2 \%$ of the total community abundance. These taxa were the most species-rich. One hundred twenty-two species represented Coleoptera, and 67 species represented Araneae. Seventy-one species among the investigated 202 species occurred 50 times or less. The distribution of plant-available moisture weighted by species abundances is multimodal and can be presented as a mixture of three normal distributions (Kolmogorov-Smirnov $d=0.037, p=0.93$ ). The plant available moisture has a 0.18 chance of the following distribution with a mean of $30.5 \mathrm{~mm}$ and variance of 11.5 . The chance is 0.66 that plant-available moisture distribution has a mean of $87.2 \mathrm{~mm}$ and a variance of 29.3. A distribution mixture component with a mean of $144.5 \mathrm{~mm}$ and variance of 6.4 has a 0.16 chance. The distribution of species tolerance to soil water content assessed based on the variance of the plant available moisture weighted by species abundances is bimodal and can be presented as a mixture of two normal distributions (Kolmogorov-Smirnov $d=$ $0.027, p=0.99$ ). A mixture distribution component with a mean of 12.6 and variance of 3.0 has a 0.17 chance. The next component with a mean of $33.5 \mathrm{~mm}$ and variance has a 0.83 chance, respectively.

HOFJO-approach provides opportunities for species response modeling using more alternative models. Model IV often is the most optimal model of the species response to a soil moisture gradient. Somewhat less often, the optimal models are III, V, and VII. Thus, species response to the soil's moisture content's influence can be described by Gaussian curve (model IV) or close to its asymmetric bell-shaped curve (model V). For ordination procedure of the community with monotonic patterns, the more appropriate is RDA, and with unimodal patterns, the more appropriate procedure is CCA (ter Braak, Prentice, 1988). DCA revealed that the length of the first axis gradient is more than two standard deviations (2.49 in our case), which points to the appropriateness of applying the correspondence analysis (CA) and the constrained correspondence analysis (CCA) as an ordination procedure.

CA-ordination axes may be explained by the environmental factors, time and spatial variables, and the technosol type. The first four CA-axes can explain $19.1 \%$ of the total community variation. Axis 1 is the most correlated with soil moisture (RAW), but a significant correlation is found between soil moisture and CA-axis 4. Temperature and atmospheric pressure are considerable predictors of the invertebrate community variation. The significance of the time predictors is strongly ranged in descending order of the temporal dbMEMs-variables. This result reveals that the importance of the time oscillations decreases with the increasing of their frequencies. The spatial predictors considerably affect the community variation. The HOFJO-approach showed that species responses to soil moisture gradient are mainly bell-shaped (for which CCA is the best ordination procedure). Nevertheless, many species' responses are monotonic (for which the RDA is the best ordination procedure). The fractioning of the animal community variability concerning meteorological data, spatial and time predictors, and the technosol type was performed based on the CCA and RDA.

The variation partitioning of the community based on CCA-approach points to the major role of the complex factors that result from the interaction of temporal and spatial factors and the temporal, spatial, and meteorological factors. The results based on RDA-approach also indicate the significant role of interaction between weather and time factors. These results point to the need to extract the role of soil moisture factor interactions with other factors to precisely assess the influence of soil moisture on the dynamics of invertebrate communities. The soil moisture influence with considering the conditional effect of the time, space, technosol type, and meteorological factors can explain $2.1 \%$ of the community variation $(F=44.04, p<0.001)$. CCA-axis statistically significantly correlates with readily available water $(r=-0.53, p<0.001)$. The statistically significant correlation of this axis with meteorological parameters, time, and space variables was not found. There is no statistically significant effect of the technosol type on this axis $(F=0.04, p=0.99)$. The species scores on CCA-axis allow us to estimate the species optimum within the humidity gradient, and the mean-square deviation of the species scores are indicators of tolerance to moisture conditions. Correlation analysis of the species' optimal values obtained by a set of methods shows a different level of relationship between these estimations. The weighted average and optimum values estimations derived from the regression model are the most correlated $(r=0.97, p<0.001)$. The regression-derived estimation corresponds to model IV, which is applied to all distributions because it provides the basic component of the correlation between the regression evaluation of the species optimums and HOFJO-assessment of the optima. Other models that consider the different levels of asymmetry or bimodality of the species' responses to soil moisture gradient provide the optimum assessments that are significantly different from the regression approach and the weighted mean method. According to the regression approach and CCA-approach, the largest deviations from the monotonous dependence between optimum estimations are seen in the central zone of the soil humidity gradient for models IV and V. Thus, considering the impact of other factors of environment, time, space, and interaction between species in a community by using the constrained ordination procedure provides a wider range of estimates of species optimum. These optimums were found in the central part of the soil humidity range (the correlation between estimation according to HOF- and CCA-approaches depending on the types of optimum models has a similar character, so it is not shown). According to CCA- 
approaches, K-mean cluster analysis of the animal species on the basis of the optimum and tolerance estimations allowed us to establish the presence of four isolated clusters. The optimal values and tolerance to the soil humidity are statistically significant different for the clusters ( $F=444.6, p<0.001$ and $F=20.7, p<0.001$ respectively).

Clusters can be meaningfully interpreted as ecological groups of animals characterized by specific relation to the soil moisture conditions. The most major ecological groups based on the relationship to moisture conditions usually are designated as hygrophilous, mesophilous, and xerophilous. Phytoindication evaluation of humidity conditions on the studied technosols indicates a range from mesophilous to xerophilous. Therefore, the species group that is the most demanding of moisture conditions we identified as mesophilous. Accordingly, the species group that can survive with water deficit conditions was identified as xerophilous. Species also show differences in tolerance to moisture conditions. Among the mesophilous species investigated are stenotopic, while xerophilous species are eurytopic. Within the humidity range between the xerophilous and the mesophilous species, two homogeneous ecological groups are transitional in terms of preferences for humidity conditions and are different concerning the tolerance. Thus, we identified stenotopic and eurytopic xeromesophilous. The total number of mesophilous species is 66 (32.7\% of the total), xerophilous - $19(9.4 \%)$, stenotopic xeromesophilous - 48 (23.8\%), and eurytopic xeromesophilous - 69 (34.2\%).

The optimum and tolerance estimations of ecological groups by CCA-approach are significantly different from the assessments by other methods. The main difference is that the soil humidity optimum assessment without considering the effect of the other environmental factors, spatial and temporal variables, and technosol type for xerophilous and xerophilous is biased in the direction of the more humid conditions. The assessment for stenotopic xeromesophilous species is biased in the direction of more dry conditions. Assessing tolerance of the species is also somewhat displaced. So, by the method of weighted mean, xerophilous species are the most stenotopic, and the level of the mesophilous tolerance is almost the same as eurytopic xeromesophilous.

The correspondence between ecological groups and the best response models from the HOFJO-list was revealed. The xerophilous species' response to humidity gradient conditions is often best described by the model $\mathrm{V}$. The response of the eurytopic xeromesophilous species is best described by model VII the response of the stenotopic xeromesophilous species is best described by model IV. For the mesophilous species, the best models are III and VI. Model II is usually best for mesophilous and stenotopic xeromesophilous species. The trophic groups also have their characteristics, typical responses to the influence of the soil moisture. For predators (116 species, $57.4 \%$ of the total), the most typical response models are III and IV (23.3 and $36.2 \%$ of the predators' total). For herbivores (116 species, $35.2 \%$ of the total), the most typical are V and VII (19.9 and $28.2 \%$ of herbivores). For saprophages (15 species, $7.4 \%$ of the total), the most typical are III and IV (33.3 and $40.0 \%$ of saprophages).

\section{Conclusion}

Moisture content in technosols is the most crucial factor determining the temporal dynamics of the terrestrial invertebrate community under semi-arid climate conditions and in an ecosystem formed from reclamation. The ecological features of the species niche, such as optimality and resilience to environmental factors, explain the community structure's temporal dynamics. The weighted mean as a way of assessing the species optimum provides only a general indication of a species' ecological preferences in the case of a unimodal model of species response. Similarly, the situation is the same for other indicators that do not include the effects of factor combinations and interspecific interactions. The combination of factors and interspecific interactions can significantly adjust the estimate of the optimum value for several species. The deviation of species responses to soil moisture effects from the symmetrical bell-shape in different parts of the soil moisture range is due to different factors. Abiotic factors dominate asymmetric responses to the physiologically more stressful ends of soil moisture gradients. Biotic factors are predominant at the extremes of the range when moisture conditions are sufficient. The failure to account for soil moisture interactions with other factors leads to a shift in species optimal estimates to the central part of the moisture range.

\section{References}

Allen, C.R., Angeler, D.G., Garmestani, A.S., Gunderson, L.H. \& Holling, C.S. (2014). Panarchy: theory and application. Ecosystems, 17(4), 578-589. DOI https://doi.org/10.1007/s10021-013-9744-2

Allen, R.G., Pereira, L.S., Raes, D. \& Smith, M. (1998). Crop evapotranspiration: guidelines for computing crop water requirements. Irrigation and Drainage Paper 56. Rome, Italy: Food and Agriculture Organization of the United Nations. 1-15.

Allen, R.G., Smith, M., Perrier, A. \& Pereira, L.S. (1994a). An update for the definition of reference evapotranspiration. ICID Bulletin 43(2), 1-34.

Allen, R.G., Smith, M., Perrier, A. \& Pereira, L.S. (1994b). An update for the definition of reference evapotranspiration. ICID Bulletin, 43(2), 35-92.

Angeler, D.G., Drakare, S. \& Johnson, R.K. (2011). Revealing the organization of complex adaptive systems through multivariate time series modeling. Ecology and Society, 16(3), 5. https://www.jstor.org/stable/26268950

Austin, M.P. (1976). On non-linear species response models in ordination. Vegetatio, 33(1), 33-41. https://doi.org/10.1007/BF00055297

Austin, M.P. (1999). A silent clash of paradigms: some inconsistencies in community ecology. Oikos, 86(1), 170-178. DOI: $10.2307 / 3546582$

Austin, M.P. (2013). Vegetation and Environment: Discontinuities and Continuities. Vegetation Ecology, Second Edition. Eddy van der Maarel and Janet Franklin. John Wiley \& Sons, Ltd. Published 2013 by John Wiley \& Sons, Ltd., 52-84. https://doi.org/10.1002/9781118452592.ch3

Baho, D. L., Futter, M. N., Johnson, R. K. \& Angeler, D. G. (2015). Assessing temporal scales and patterns in time series: Comparing methods based on redundancy analysis. Ecological Complexity, 22, 162-168. https://doi.org/10.1016/j.ecocom.2015.04.001 
Beck, J. \& Kitching, I.J. (2007). Correlates of range size and dispersal ability: a comparative analysis of sphingid moths from the Indo-Austalian tropics. Global Ecology and Biogeography, 16, 341-349. https://doi.org/10.1111/j.1466-8238.2007.00289.x

Bertness, M. \& Callaway, R.M. (1994). Positive interactions in communities. Trends in Ecology and Evolution, 9(5), 191-193. https://doi.org/10.1016/0169-5347(94)90088-4

Bonsall, M.B. \& Hastings, A. (2004). Demographic and environmental stochasticity in predator-prey metapopulation dynamics. Journal of Animal Ecology, 73, 1043-1055. https://doi.org/10.1111/j.0021-8790.2004.00874.x

Bonte, D., Baert, L. \& Maelfait, J.-P. (2002). Spider assemblage structure and stability in a heterogenous coastal dune system (Belgium). Journal of Arachnology, 30, 331-343. doi: 10.1636/0161-8202(2002)030[0331:SASASI]2.0.CO;2

Borcard, D. \& Legendre, P. (2002). All-scale spatial analysis of ecological data by means of principal coordinates of neighbour matrices. Ecological Modelling, 153, 51-68.

Borcard, D., Legendre, P., Avois-Jacquet, C. \& Tuosimoto, H. (2004). Dissecting the spatial structure of ecological data at multiple scales. Ecology, 85, 1826-1832.

Bowker, M. A., Soliveres, S. \& Maestre, F. T. (2010). Competition increases with abiotic stress and regulates the diversity of biological soil crusts. Journal of Ecology, 98(3), 551-560. doi:10.1111/j.1365-2745.2010.01647.x

Brandle, M., Durka, W., Krug, H. \& Brandl, R. (2003). The assembly of local communities: plants and birds in non-reclaimed mining sites. Ecography, 26, 652-660. doi: 10.1034/j.1600-0587.2003.03513.x

Brandle, M., Ohlschlager, S. \& Brandl, R. (2002). Range size in butterflies: correlation across scales. Evolutionary Ecology Research, 4, 993-1004.

Brown, J. H. (1984). On the relationship between abundance and distribution of species. The American Naturalist, 124, $255-279$.

Brown, J.H. (1999). Macroecology: progress and prospect. Oikos, 87, 3-14. DOI: 10.2307/3546991

Buchholz, S. (2009). Community structure of spiders in coastal habitats of a Mediterranean delta region (Nestos Delta, NE Greece). Animal Biodiversity and Conservation, 32(2). 101-115.

Buchori, D., Rizali, A., Rahayu, G.A. \& Mansur, I. (2018). Insect diversity in post-mining areas: Investigating their potential role as bioindicator of reclamation success. Biodiversitas, 19, 1696-1702. DOI: 10.13057/biodiv/d190515

Burnham, K.P. \& Anderson, D.R. (2002). Model selection and multi-model inference: a practical information-theoretic approach. Berlin: Springer.

Buzuk, G. N. (2017). Phytoindication with ecological scales and regression analysis: environmental index. Bulletin of Pharmacy, 2 (76), 31-37.

Chang, L.-W., Zelený, D., Li, C.-F., Chiu, S.-T. \& Hsieh, C.-F. (2013). Better environmental data may reverse conclusions about niche-and dispersal-based processes in community assembly. Ecology, 94, 2145-2151. https://doi.org/10.1890/12-2053.1

Chase, J. M. \& Myers, J. A. (2011). Disentangling the importance of ecological niches from stochastic processes across scales. Philosophical Transactions of the Royal Society B: Biological Sciences, 366, 2351-2363. https://doi.org/10.1098/rstb.2011.0063

Chase, J. M., M. A. Leibold, A. L. Downing, \& J. B. Shurin. (2000). The effects of productivity, herbivory, and plant species turnover in grassland food webs. Ecology, 81(9), 2485-2497. https://doi.org/10.1890/0012-9658(2000)081[2485:TEOPHA]2.0.CO;2

Collins, S.L., Belnap, J., Grimm, N.B., Rudgers, J.A., Dahm, C.N., D'Odorico, P., Litvak, M., Natvig, D.O., Peters, D.C., Pockman, W.T., Sinsabaugh, R.L. \& Wolf, B.O. (2014). A multiscale, hierarchical model of pulse dynamics in arid-land ecosystems. Annual Review of Ecology, Evolution, and Systematics, 45, 397-419. https://doi.org/10.1146/annurev-ecolsys-120213-091650

Colwell, R.K. \& Futuyma, D.J. (1971). Measurement of niche breadth and overlap. Ecology, 52, 567-576. DOI: 10.2307/1934144

Cottenie, K., (2005). Integrating environmental and spatial processes in ecological community dynamics. Ecology Letters, 8, 11751182. doi:10.1111/j.1461-0248.2005.00820.x

Curtis, J. T., \& Mclntosh R. P. (1951). An Upland Forest Continuum in the Prairie-Forest Border Region of Wisconsin. Ecology, 32, 476-496. https://doi.org/10.2307/1931725

David, J.F., \& Handa, I.T. ( 2010). The ecology of saprophagous macroarthropods (millipedes, woodlice) in the context of global change. Biological Reviews, 85(4), 881-895. doi: 10.1111/j.1469-185X.2010.00138.x.

Desender, K., Ervinck, A. \& Tack, G. (1999). Beetle diversity and historical ecology of woodlands in Flanders. Belgian Journal of Zoology, 129(1), 139-155.

Devictor, V., Clavel, J., Julliard, R., Lavergne, S., Mouillot, D., Thuiller, W., Venail, P., Villéger, S., \& Mouquet, N. (2010). Defining and measuring ecological specialization. Journal of Applied Ecology, 47, 15-25. doi:10.1111/j.1365-2664.2009.01744.x

Didukh, Y. P. (2011). The ecological scales for the species of Ukrainian flora and their use in synphytoindication. Kyiv: Phytosociocentre.

Dray, S., Legendre, P. \& Peres-Neto, P. (2006). Spatial modelling: a comprehensive framework for principal coordinate analysis of neighbours matrices (PCNM). Ecological Modelling, 196, 483-493.

Dray, S., Pélissier, R., Couteron, P., Fortin, M.-J., Legendre, P., Peres-Neto, P. R., Bellier, E., Bivand, R., Blanchet, F. G., De Cáceres, M., Dufour, A.-B., Heegaard, E., Jombart, T., Munoz, F., Oksanen, J., Thioulouse, J. \& Wagner, H. H. (2012). Community ecology in the age of multivariate multiscale spatial analysis. Ecological Monographs, 82, 257-275. https://doi.org/10.1890/11-1183.1

Dunger, W., Wanner, M., Hauser, H., Hohberg, K., Schulz, H.-J., Schwalbe, T., Seifert, B., Vogel, J., Voigtländer, K., Zimdars, B. \& Zulka, K.P. (2001). Development of soil fauna at mine sites during 46 years after afforestation. Pedobiologia, 45(3), 243-271. https://doi.org/10.1078/0031-4056-00083.

Dvorský, M., Macek, M., Kopecký, M., Wild, J. \& Doležal, J. (2017). Niche asymmetry of vascular plants increases with elevation. Journal of Biogeography, 44(6), 1418-1425. doi:10.1111/jbi.13001

Elton, C. (1927). Animal Ecology. Sidgwick and Jackson, London. 
Entling, W., Schmidt, M. H., Bacher, S., Brandl, R., \& Nentwig, W. (2007). Niche properties of Central European spiders: shading, moisture and the evolution of the habitat niche. Global Ecology and Biogeography, 16, 440-448. doi:10.1111/j.14668238.2006.00305.x

Evett, S.R., Prueger, J.H. \& Tolk, J.A. (2011). Water and energy balances in the soil-plantatmosphere continuum. In: Huang, P.M., Li, Y., Sumner, M.E. (Eds.). Handbook of soil sciences: properties and processes. 2nd ed. Boca Raton, Florida, USA: CRC Press. 6-1-6-44.

Gallé, R., Vesztergom, N. \& Somogyi, T. (2011). Environmental conditions affecting spiders in grasslands at the lower reach of the River Tisza in Hungary. Entomologica Fennica, 22, 29-38.

Gaston, K.J., Blackburn, T.M., \& Lawton, J.H. (1997). Interspecific abundance-range size relationships: an appraisal of mechanisms. Journal of Animal Ecology, 66(44), 579-601. doi: 10.2307/5951

Gauch, H. G. \& Whittaker, R. H. (1972). Coenocline simulation. Ecology, 53(3), 446-451. https://doi.org/10.2307/1934231

Ge B., Daizhen, Z., Jun, C., Huabin, Z., Chunlin, Z. \& Boping, T. (2014). Biodiversity Variations of Soil Macrofauna Communitiesin Forestsina Reclaimed Coastwith Different Diked History. Pakistan Journal of Zoology, 46(4). 1053-1059.

Gerlach, J., Samways, M. \& Pryke, J. (2013). Terrestrial invertebrates as bioindicators: an overview of available taxonomic groups. Journal of Insect Conservation, 17(4), 831-850. https://doi.org/10.1007/s10841-013-9565-9

Gregory, R.D. \& Gaston, K.J. (2000). Explanations of commonness and rarity in British breeding birds: separating resource use and resource availability. Oikos, 88, 515-526. https://doi.org/10.1034/j.1600-0706.2000.880307.x

Grinnell, J. (1917). The niche relationship of the California Thrasher. The Auk: Ornithological Advances, 34(4), 427-433. https://doi.org/10.2307/4072271

Hedde, M., Nahmani, J., Séré, G., Auclerc, A. \& Cortet J. (2018). Early colonisationof constructed technosols by macroinvertebrates. Journal of Soils and Sediments, https://doi.org/10.1007/s11368-018-2142-9

Heegaard, E. (2002). The outer border and central border for species-environmental relationships estimated by non-parametric generalised additive models. Ecological Modelling, 157(2-3), 131-139. https://doi.org/10.1016/S0304-3800(02)00191-6

Hendrychova, M. (2008). Reclamation success in post-mining landscapes in the Czech Republic: a review of pedological and biological studies. Journal of Landscape Studies, 1, 63-78.

Hendrychova, M., Salek, M., Tajovsky, K., \& Reho, M. (2011). Soil properties and species richness of invertebrates on afforested sites after brown coal mining. Restoration Ecology, 20 (5), 561-567. https://doi.org/10.1111/j.1526-100X.2011.00841.x

Hendrychová, M., Šálek, M. \& Červenková, A. (2008). Invertebrate communities in man-made and spontaneously developed forests on spoil heaps after coal mining. Journal of Landscape Studies, 1, 169-187.

Hendrychová, M., Šálek, M., Tajovský, K. \& Řehoř, M. (2012), Soil Properties and Species Richness of Invertebrates on Afforested Sites after Brown Coal Mining. Restoration Ecology, 20(5), 561-567. doi:10.1111/j.1526-100X.2011.00841.x

Hering, R., Hauptfleisch, M., Geißler, K., Marquart, A., Schoenen, M. \& Blaum, N. (2019). Shrub encroachment is not always land degradation: Insights from ground-dwelling beetle species niches along a shrub cover gradient in a semi-arid Namibian savanna. Land Degradation \& Devilopment, 30(1), 14- 24. https://doi.org/10.1002/ldr.3197

Hess, T. M. (1996). Evapotranspiration estimates for water balance scheduling in the UK. Irrigation News, 25, 31-36.

Hildmann, E., \& Wunsche, M. (1996). Lignite mining and its after-effects on the central German landscape. Water, Air and Soil Pollution, (91), 79-87. doi: https://doi.org/10.1007/BF00280924

Hill, M.O. (1973). Reciprocal averaging: an eigenvector method of ordination. Journal of Ecology, 61(1), 237-249. DOI: 10.2307/2258931

Hodecek, J., Kuras, T., Sipos, J. \& Dolny, A. (2016). Role of reclamation in the formation of functional structure of beetle communities: A different approach to restoration. Ecological Engineering, 94, 537-544. https://doi.org/10.1016/j.ecoleng.2016.06.027

Hodecek, J., Kuras, T., Sipos, J. \& Dolny, A., (2015). Post-industrial areas as successional habitats: long-term changes of functional diversity in beetle communities. Basic and Applied Ecology, 16(7), 629-640. https://doi.org/10.1016/j.baae.2015.06.004

Huisman, J., Olff, H. \& Fresco, L.F.M. (1993). A hierarchical set of models for species response analysis. Journal of Vegetation Science, 4(1), 37-46. https://doi.org/10.2307/3235732

Hutchinson, G. E. (1957). Concluding remarks. Cold Spring Harbour Symposium on Quantitative Biology, 22, 415-427. http://dx.doi.org/10.1101/SQB.1957.022.01.039

Inbar, M., Doostdar, H. \& Mayer, R. T. (2001). Suitability of stressed and vigorous plants to various insect herbivores. Oikos, 94(2), 228-235. doi: 10.1034/j.1600-0706.2001.940203.x

Jabloun, M. \& Sahli, A. (2008). Evaluation of FAO-56 methodology for estimating reference evapotranspiration using limited climatic data: Application to Tunisia. Agricultural Water Management, 95(6), 707-715. https://doi.org/10.1016/j.agwat.2008.01.009

Jamil, T., \& ter Braak, C. J. F. (2013). Generalized linear mixed models can detect unimodal species-environment relationships. PeerJ, 1:e95. doi: 10.7717/peerj.95

Jansen, F., \& Oksanen, J. (2013). How to model species responses along ecological gradients - Huisman-Olff-Fresco models revisited. Journal of Vegetation Science, 24, 1108-1117. https://doi.org/10.1111/jvs.12050

Kędzior, R. (2018). Co-occurrence pattern of ground beetle (Coleoptera, Carabidae) indicates the quality of restoration practices in postindustrial areas. Applied Ecology and Environmental Research, 16(6), 7913-7924. DOI: http://dx.doi.org/10.15666/aeer/1606_79137924

Kielhorn, K.H., Keplin, B. \& Hüttl, R.F. (1999). Ground beetle communities on reclaimed mine spoil: Effects of organic matter application and revegetation. Plant and Soil, 213(1-2), 117-125. https://doi.org/10.1023/A:1004508317091

Klimkina, I., Kharytonov, M. \& Zhukov, O. (2018). Trend Analysis of Water-Soluble Salts Vertical Migration in Technogenic Edaphotops of Reclaimed Mine Dumps in Western Donbass (Ukraine). Journal of Environmental Research, Engineering and Management, 74 (2), 82-93. http://dx.doi.org/10.5755/j01.erem.74.2.19940 
Knapp, M., Seidl, M., Knappová, J., Macek, M., \& Saska, P. (2019). Temporal changes in the spatial distribution of carabid beetles around arable field-woodlot boundaries. Scientific reports, 9(1), 8967. doi: 10.1038/s41598-019-45378-7

Kohn, A. J. (1968). Microhabitats, abundance, and food of Conus in the Maldive and Chagos Islands. Ecology, 49, $1046-1061$. https://doi.org/10.2307/1934489

Konstantinov, A.S., Korotyaev, B.A. \& Volkovitsh, M.G., (2009). Insect biodiversity in the Palearctic region. In: Foottit, R., Adler, P. (Eds.), Insect Biodiversity: Science and Society. Blackwell Publisher, Chinchester, pp. 107-162.

Kunah, O. M., Zelenko, Y. V., Fedushko, M. P., Babchenko, A. V., Sirovatko, V. O., \& Zhukov, O. V. (2019). The temporal dynamics of readily available soil moisture for plants in the technosols of the Nikopol Manganese Ore Basin. Biosystems Diversity, 27(2), 156-162. doi:10.15421/011921

Kunakh, O.N., Kramarenko, S.S., Zhukov, A.V., Zadorozhnaya, G.A. \& Kramarenko, A.S. (2018). Intra-population spatial structure of the land snail Vallonia pulchella (Müller, 1774) (Gastropoda; Pulmonata; Valloniidae). Ruthenica, 28 (3), 91-99.

La Notte, A., D'Amato, D., Mäkinen, H., Paracchini, M.L., Liquete, C., Egoh, B., Geneletti, D. \& Crossman, N.D. (2017). Ecosystem services classification: A systems ecology perspective of the cascade framework. Ecological Indicators, 74, 392-402. https://doi.org/10.1016/j.ecolind.2016.11.030

Laporta, G. Z. \& Sallum, M. A. M. (2014). Coexistence mechanisms at multiple scales in mosquito assemblages. BMC Ecology, 14(1), 30. DOI: 10.1186/s12898-014-0030-8

Lavelle, P., Bignell, D., Lepage, M., Wolters, V., Roger, P., Ineson, P., Heal, O.W. \& Dhillion, S. (1997). Soil function in a changing world: the role of invertebrate ecosystem engineers. European Journal of Soil Science, 33, 159-193.

Lawton, J.H. (1999). Are there general laws in ecology? Oikos, 84, 177-192. DOI: 10.2307/3546712

Legendre, P., \& Birks, H. J. B. (2012). From classical to canonical ordination. In Birks, H. J. B., Lotter, A. F., Juggins, S. \& Smol, J. P. (Eds.), Tracking Environmental Change using Lake Sediments: Data handling and numerical techniques. 5, (pp. 201-248), Dordrecht, Springer.

Legendre, P. \& Gallagher, E. D. (2001). Ecologically meaningful transformations for ordination of species. Oecologia, 129(2), 271280. DOI https://doi.org/10.1007/s004420100716

Levin, S.A., (1992). The problem of pattern and scale in ecology. Ecology, 73, 1943-1967. https://doi.org/10.2307/1941447

Liu, J.-L., Li, F.-R., Sun, T.-S., Ma, L.-F., Liu, L.-L. \& Yang, K. (2016). Interactive effects of vegetation and soil determine the composition and diversity of Carabid and Tenebrionid functional groups in an arid ecosystem. Journal of Arid Environments, 128, 80-90. https://doi.org/10.1016/j.jaridenv.2016.01.009

Lososová, Z., Šmarda, P., Chytrý, M., Purschke, O., Pyšek, P., Sádlo, J., Tichý, L. \& Winter, M. (2015). Phylogenetic structure of plant species pools reflects habitat age on the geological time scale. Journal of Vegetation Science, 26, 1080-1089. doi:10.1111/jvs.12308

Madej, G. \& Kozub, M. (2014). Possibilities of using soil microarthropods, with emphasis on mites (Arachnida, Acari, Mesostigmata), in assessment of successional stages in a reclaimed coal mine dump (Pszów, S Poland). Biological Letters, 51(1), 19-36. doi: 10.1515/biolet-2015-0003

Mallis, R.E. \& Hurd, L.E. (2005). Diversity among ground dwelling spider assemblages: habitat generalists and specialists. Journal of Arachnology, 33, 101-109. DOI: 10.1636/M03-34

Maraun, M., Martens, H., Migge, S., Theenhaus, A. \& Scheu, S. (2003). Adding to 'the enigma of soil animal diversity': fungal feeders and saprophagous soil invertebrates prefer similar food substrates. European Journal of Soil Biology, 39, 85-95. https://doi.org/10.1016/S1164-5563(03)00006-2

Marc, P., Canard, A. \& Ysnel F. (1999). Spiders (Araneae) useful for pest limitation and bioindication. Agriculture, Ecosystems and Environment, 74, 229-273. http://dx.doi.org/10.1016/S0167-8809(99)00038-9

Michaelis J., \& Diekmann, M.R. (2017). Biased niches - Species response curves and niche attributes from Huisman-Olff-Fresco models change with differing species prevalence and frequency. PLOS ONE, 12(8), e0183152.https://doi.org/10.1371/journal.pone.0183152

Minchin, P.R. (1987). An evaluation of the relative robustness of techniques for ecological ordination. Vegetatio, 69(1-3), 89-107. https://doi.org/10.1007/BF00038690

Monteith, J.L. (1965). Evaporation and the environment. In: The State and Movement of Water in Living Organisms, 19th Symposium of the Society for Experimental Biology, London, Cambridge University Press, 205-234.

Morón-Ríos, A., Rodríguez, M. Á., Pérez-Camacho, L. \& Rebollo, S. (2010). Effects of seasonal grazing and precipitation regime on the soil macroinvertebrates of a Mediterranean old-field. European Journal of Soil Biology, 46(2), 91-96. https://doi.org/10.1016/j.ejsobi.2009.12.008.

Nash, K.L., Allen, C.R., Angeler, D.G., Barichievy, C., Eason, T., Garmestani, A.S., Graham, N.A.J., Granholm, D., Knutson, M., Nelson, R.J., Nystrom, M., Stow, C.A. \& Sundstrom, S.M., (2014). Discontinuities, cross-scale patterns, and the organization of ecosystems. Ecology, 95, 654-667. https://doi.org/10.1890/13-1315.1

Okie, J. G., Van Horn, D. J., Storch, D., Barrett, J. E., Gooseff, M. N., Kopsova, L., \& Takacs-Vesbach, C. D. (2015). Niche and metabolic principles explain patterns of diversity and distribution: theory and a case study with soil bacterial communities. Philosophical Transactions of the Royal Society B: Biological Sciences, 282, 20142630. http://dx.doi.org/10.1098/rspb.2014.2630

Oksanen, J. (2004). Multivariate Analysis in Ecology. Lecture Notes. Department of Biology, Universityof Oulu. http://cc.oulu.fi/ jarioksa/opetus/metodi/notes.pdf

Oksanen, J., Blanchet, F. G., Kindt, R., Legendre, P., Minchin, P.R., O'Hara, R.B., Simpson, G.L., Solymos, P., Stevens, M. H. H. \& Wagner, H. (2018). Community Ecology Package. R package version 2.5-2. https://CRAN.R-project.org/package=vegan

Paoletti, M. G. \& Hassall, M. (1999). Woodlice (Isopoda: Oniscidea): their potential for assessing sustainability and use as bioindicators. Agriculture, Ecosystems and Environment, 74(1-3), 157-165. https://doi.org/10.1016/S0167-8809(99)00027-4 
Paoletti, M.G., Osler, G.H.R., Kinnear, A., Black, D.J., Thomson, L.J., Tsitsilas, A., Sharley, D., Judd, S., Neville, P. \& D'inca, A. (2007). Detritivores as indicators of landscape stress and soil degradation. Australian Journal of Experimental Agriculture, 47(4), 412423. doi: 10.1071/EA05297

Penman, H.L., (1948). Natural evaporation from open water, bare soil, and grass. Proceedings of the Royal Society of London. Series A, Mathematical and Physical Sciences, 193(1032), 120-145. http://www.jstor.org/stable/98151

Pereira, L. S., Cai, L. G. \& Hann, M. J. (2003). Farm water and soil management for improved water use in the North China Plain. Irrigation and Drainage, 52(4), 299-317. https://doi.org/10.1002/ird.98

Pontegnie, M., du Bus de Warnaffe, G. \& Lebruna, Ph. (2005). Impacts of silvicultural practices on the structure of hemi-edaphic macrofauna community. Pedobiologia, 49(3), 199-210. doi: 10.1016/j.pedobi.2004.09.005

Popova, Z., Eneva, S., \& Pereira, L. S. (2006). Model validation, crop coefficients and yield response factors for maize irrigation scheduling based on long-term experiments. Biosystems Engineering, 95(1), 139-149. https://doi.org/10.1016/j.biosystemseng.2006.05.013

Price, P. W. (1991). The Plant Vigor Hypothesis and Herbivore Attack. Oikos, 62 (2), 244-251. doi: 10.2307/3545270

Purse, B. V., Gregory, S. J., Harding, P. \& Roy, H. E. (2012). Habitat use governs distribution patterns of saprophagous (littertransforming) macroarthropods - a case study of British woodlice (Isopoda: Oniscidea). European Journal of Entomology, 109 543-552. doi: 10.14411/eje.2012.068

Rao, C.R. (1995). A review of canonical coordinates and an alternative to correspondence analysis using Hellinger distance. Qüestiió, 19(1-3), 23-63. http://hdl.handle.net/2099/4059

Rehor, M., Lang, T. \& Eis, M. (2006). Application of new methods in solving current reclamation issues of Severoceske doly, a.s. localities. World of Surface Mining, 6, 383-386.

Reynolds, J.F., Smith, D.M.S., Lambin, E.F., Turner, B.L., Mortimore, M., Batterbury, S.P., Downing, T.E., Dowlatabadi, H., Fernández, R.J., Herrick, J.E., Huber-Sannwald, E., Jiang, H., Leemans, R., Lynam, T., Maestre, F.T., Ayarza, M. \& Walker, B. (2007). Global desertification: building a science for dryland development. Science, 316(5826), 847-51. doi: 10.1126/science.1131634

Rushton, S.P. \& Eyre, M.D. (1992). Grassland spider habitats in north-east England. Journal of Biogeography, 19, 99-108. doi: $10.2307 / 2845623$

Schoener, T.W. (1974). The compression hypothesis and temporal resource partitioning. Proceedings of the National Academy of Sciences, 71(10), 4169-4172. doi: 10.1073/pnas.71.10.4169

Schwinning, S. \& Sala, O.E. (2004). Hierarchy of responses to resource pulses in arid and semi-arid ecosystems. Oecologia, 141(2), 211-220. DOI: 10.1007/s00442-004-1520-8

Silvertown, J., McConway, K., Gowing, D., Dodd, M., Fay, M.F., Joseph, J.A. \& Dolphin, K. (2006). Absence of phylogenetic signal in the niche structure of meadow plant communities. Proceedings of the Royal Society of London, Series B, 273, 39-44.

Sklenicka, P., Prikryl, I., Svoboda, I. \& Lhota, T. (2004). Non-productive principles of landscape rehabilitation after long-term opencast mining in north-west Bohemia. Journal of the South African Institute of Mining and Metallurgy, 104, 83-88.

Slabbers, P. J. (1980). Practical prediction of actual evapotranspiration. Irrigation Science, 1(3), 185-196. https://doi.org/10.1007/BF00270883

Šmilauer, P. \& Lepš, J. (2014). Multivariate Analysis of Ecological Data using CANOCO 5. Cambridge: Cambridge University Press. doi: $10.1017 / C B O 9781139627061$

Soberon, J. (2007). Grinnellian and Eltonian niches and geographic distributions of species. Ecology Letters, 10(12), 1115-1123. https://doi.org/10.1111/j.1461-0248.2007.01107.x

Souty-Grosset, C., Badenhausser, I., Reynolds, J.D. \& Morel, A. (2005). Investigations on the potential of woodlice as bioindicators of grassland habitat quality. European Journal of Soil Biology, 41(3), 109-116. doi: 10.1016/j.ejsobi.2005.09.009

Spanbauer, T.L., Allen, C.R., Angeler, D.G., Eason, T., Fritz, S.C., Garmestani, A.S., Nash, K.L. \& Stone, J.R. (2014). Prolonged instability prior to a regime shift. PLoS ONE, 9, e108936. https://doi.org/10.1371/journal.pone.0108936

Szczepanska, J. \& Twardowska, I., (1999). Distribution and environmental impact of coal-mining wastes in Upper Silesia Poland. Environmental Geology. 38, 249-258. DOl https://doi.org/10.1007/s002540050422

Tarjuelo, R., Morales, M. B., Arroyo, B., Mañosa, S., Bota, G., Casas, F., \& Traba, J. (2017). Intraspecific and interspecific competition induces density-dependent habitat niche shifts in an endangered steppe bird. Ecology and evolution, 7(22), 97209730. doi:10.1002/ece3.3444

ter Braak C, J. F. (1985). Correspondence Analysis of Incidence and Abundance Data: Properties in Terms of a Unimodal Response Model. Biometrics, 41(4), 859-73. DOI: 10.2307/2530959

ter Braak, C. J. F., \& Smilauer, P. (2015). Topics in constrained and unconstrained ordination. Plant Ecology, 216(5), 683-696. https://doi.org/10.1007/s11258-014-0356-5

ter Braak, C.J.F. \& Smilauer, P. (2002) Canoco reference manual and CanoDraw for Windows user's guide. Biometris, Wageningen.

ter Braak, C.J.F., \& Looman, C.W.N. (1986). Weighted averaging, logistic regression and the Gaussian response model. Vegetatio, 65, 3-11. https://doi.org/10.1007/BF00032121

ter Braak, C.J.F. \& Prentice, I.C. (1988). A theory of gradient analysis. Advances in Ecological Research, 18, $271-317$.

Tokeshi, M. (1999) Species coexistence: ecological and evolutionary perspectives. Blackwell Science, London.

Trotter, R. T., Cobb, N. S. \& Whitham, T. G. (2008). Arthropod community diversity and trophic structure: a comparison between extremes of plant stress. Ecological Entomology, 33, 1-11. doi:10.1111/j.1365-2311.2007.00941.x

Warburg, M.R., Linsenmair, K.E. \& Bercovitz, K. (1984). The effect of climate on the distribution and abundance of Isopods. Symposia of the Zoological Society of London, 53, 339-367.

Westhoff, V. \& van der Maarel, E. (1978). The Braun-Blanquet approach. In: Whittaker, R.H. (Ed.), Classification of Plant Communities, pp. 289-399. 
White, T.C.R. (1976). Weather, food, and plagues of locusts. Oecologia, 22(2), 119 - 134. DOI https://doi.org/10.1007/BF00344712

White, T.C.R. (1984). The abundance of invertebrate herbivores in relation to the availability of nitrogen in stressed food plants. Oecologia, 63(1), 90-105. https://doi.org/10.1007/BF00379790

Wise, D. H. (1993). Spiders in ecological webs. Cambridge University Press, Cambridge.

Yorkina, N., Maslikova, K., Kunah, O. \& Zhukov, O. (2018). Analysis of the spatial organization of Vallonia pulchella (Muller, 1774) ecological niche in Technosols (Nikopol manganese ore basin, Ukraine). Ecologica Montenegrina, 17, 29-45.

Yorkina, N., Zhukov, O. \& Chromysheva, O. (2019). Potential possibilities of soil mesofauna usage for biodiagnostics of soil contamination by heavy metals. Ekológia (Bratislava), 38 (1), 1-10. doi: 10.2478/eko-2019-0001

Zhenqi, H., Peijun, W. \& Jing, L. (2012). Ecological Restoration of Abandoned Mine Land in China. Journal of Resources and Ecology, 3(4), 289-296. DOI:10.5814/j.issn.1674-764x.2012.04.001

Zadorozhnaya, G. A., Andrusevych, K.V. \& Zhukov, O.V. (2018). Soil heterogeneity after recultivation: ecological aspect. Folia Oecologica, 45 (1), 46-52. doi: 10.2478/foecol-2018-0005

Zhukov, O., Kunah, O., Dubinina, Y. \& Novikova, V. (2018). The role of edaphic and vegetation factors in structuring beta diversity of the soil macrofauna community of the Dnipro river arena terrace. Ekológia (Bratislava), 37, 3, 301-327. doi: 10.2478/eko2018-0023

Zhukov, A. \& Gadorozhnaya, G. (2016). Spatial heterogeneity of mechanical impedance of a typical chernozem: the ecological approach. Ekológia (Bratislava), 35, 263-278. DOI: https://doi.org/10.1515/eko-2016-0021

Zhukov, O. V. \& Maslikova, K. P. (2018). The dependence of the technosols models functional properties from the primary stratigraphy designs. Journal of Geology, Geography and Geoecology, 27(2), 399-407. doi: 10.15421/111864

\section{Citation:}

Babchenko, A.V., Fedushko, M.P., Timchiy, E.I., Huska, Yu.A., Khalus, S.V. (2020). The response of invertebrate communities to a moisture gradient in artificial soils of Ukrainian steppe arid zone. Ukrainian Journal of Ecology, 10(6), 338-350.

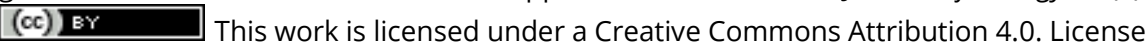

